Soil Environ. 36(2): 197-206, 2017

DOI:10.25252/SE/17/51189

Online ISSN: 2075-1141

Print ISSN: 2074-9546

\title{
Field application of ACC-deaminase biotechnology for improving chickpea productivity in Bahawalpur
}

\author{
Maqshoof Ahamd ${ }^{I^{*}}$, Zahir Ahmad Zahir ${ }^{2}$, Moazzam Jamil $^{l}$, Farheen Nazli ${ }^{3}$ and Zafar Iqbal ${ }^{1}$ \\ ${ }^{1}$ Department of Soil Science, University College of Agriculture and Environmental Sciences, the Islamia University of \\ Bahawalpur, Bahawalpur \\ ${ }^{2}$ Institute of Soil and Environmental Sciences, University of Agriculture, Faisalabad, Pakistan \\ ${ }^{3}$ Pesticide Quality Control Laboratory, Bahawalpur
}

\begin{abstract}
The use of biofertilizer in crop production is gaining importance in modern agriculture, especially under stressful environments. In drought-hit areas of the world, improvement in drought tolerance of major food crops is one of the way forwards to ensure food security. Under water limited conditions, the use of ACC-deaminase biofertilizers can mitigate the adverse effects of drought stress on crop production. Present study was conducted for the field evaluation of ACC-deaminase based biofertilizer (Rhizobium and Pseudomonas strains) for improving chickpea productivity in Bahawalpur. Six field trials were conducted in different villages of Bahawalpur. Biofertilizer alone and in combination with enriched compost was evaluated under field conditions. Different treatments used in the experiment were control, P-Enriched compost, biofertilizer and P-Enriched compost + biofertilizer. The experiments were conducted in Randomized Complete Block Design with three replications. Results showed that enriched compost and biofertilizer, individually and in combination significantly improved the number of nodules plant ${ }^{-1}$, nodules fresh weight and nodules dry weight of chickpea. The combined application of $P$ enriched compost and biofertilizer resulted in maximum increase in number of nodules plant ${ }^{-1}$ and nodules dry weight as compared to control. The integrated use also gave better results in improving plant height and shoot dry weight, yield, number of pods plant ${ }^{-1}$, number of grains pod ${ }^{-1}$, and 1000 grain weight as compared to separate use of biofertilizer and P-enriched compost. A significant increase in nitrogen and phosphorus contents of chickpea was also observed with combined application of biofertilizer and compost. It can be concluded that the integrated use of ACC-deaminase containing biofertilizer and P-enriched compost is an effective biotechnology to improve chickpea productivity under field conditions and should be recommended to the farmers in the region, where water shortage is the main hindrance to agricultural sustainability.
\end{abstract}

Key words: Water shortage, agriculture sustainability, ACC-deaminase biotechnology, food

\section{Introduction}

Chickpea is one of the important pulses in human diet and is cultivated in over 50 countries worldwide. Its total global production during 2014 was 14 million tons (FAO, 2015) that is third among the pulse crops during that year. It is a rich source of protein along with minerals (calcium, magnesium, phosphorus, zinc and iron), $\beta$-carotene and vitamins (Jukanti et al., 2012). The protein quality of chickpea is better than other available sources and is more economical to produce thus affordable for poor people (Arnoldi et al., 2015). In addition to its importance in human diet, chickpea can also improve soil fertility by fixing atmospheric nitrogen with the help of Rhizobia present in root nodules (Duc et al., 2014; Rubiales and Mikic, 2015).

Chickpea can be a good alternative to grain crops in arid and semi-arid climates where water availability is an issue. It is a hardy crop that can easily and successfully be grown with limited availability of water (Singh and Mukherjee, 2009). However, according to available reports, the yield of chickpea is unstable and unpredictable due to number of biotic and abiotic stresses including precipitation in rain-fed areas (FAO, 2015). These stresses pose a number of adverse effects on crop growth and productivity including decreased photosynthetic rate, less water use efficiency, nutritional imbalance (Ahmad et al., 2013a, 2014) and higher levels of ethylene production (Nadeem et al., 2014). The higher levels of ethylene inhibit seed germination, root elongation and nodulation in legumes (Shaharoona et al., 2006).

The ACC deaminase containing plant growth promoting rhizobacteria (PGPR) have the ability to induce stress tolerance in crop plants (Ahmad et al., 2011) thus enabling them to withstand periods of drought and other stresses. Under limited water availability, these PGPR use different mechanisms for crop improvement including increased

*Email: maqshoof_ahmad@yahoo.com 
moisture availability, enhanced nutrient acquisition, phytohormones production and decreased ethylene production due to ACC deaminase activity (Bent et al., 2001). Also, the careful selection and inoculation with efficient rhizobial strains can improve the nodulation in legume crops (Ahmad et al., 2011) as some of them can survive well under drought stress as compared to others (Hussain et al., 2014). These rhizobia facilitate the growth of their host plant by fixing atmospheric nitrogen, antibiotics production, siderophores production, and solubilization of minerals (Patten and Glick, 2002). The combined use of these rhizobia and PGPR can be an efficient an environmental friendly approach to improve the growth and productivity of crop plants under unfavourable environmental conditions (Selvakumar et al., 2012; Ahmad et al., 2013b; Nadeem et al., 2014). Thus, the use of multistrain biofertilizers containing efficient strains of ACC deaminase producing rhizobacteria and Rhizobia can be a resourceful biotechnology for improving growth and productivity of chickpea under limited availability of water.

Keeping in view the entire scenario, a multi-strain biofertilizer containing novel strains (Mesorhizobium cicri,
Pseudomonas sp. and Bacillus sp.) was developed through a series of experiments under laboratory, green house, and field conditions. In the present paper, we report the results of experiments conducted on farmer's fields at Bahawalpur to evaluate the use of biofertilizer for improving chickpea productivity under limited water resources.

\section{Materials and Methods}

\section{Preparation of biofertilizer}

Biofertilizer was prepared at the using novel strains of Mesorhizobium cicri, Pseudomonas sp. and Bacillus sp. at University of Agriculture Faisalabad. The already installed biofertilizer production unit was used to prepare biofertilizer. The biofertilizer was used to inoculate the seed for field experiments.

\section{Sowing of crop in the field}

Field trials were conducted at six locations in different villages of Bahawalpur zone (Figure 1 and 2). The chickpea crop was sown in November, 2014 according to the treatment plan viz. control, P-enriched compost,

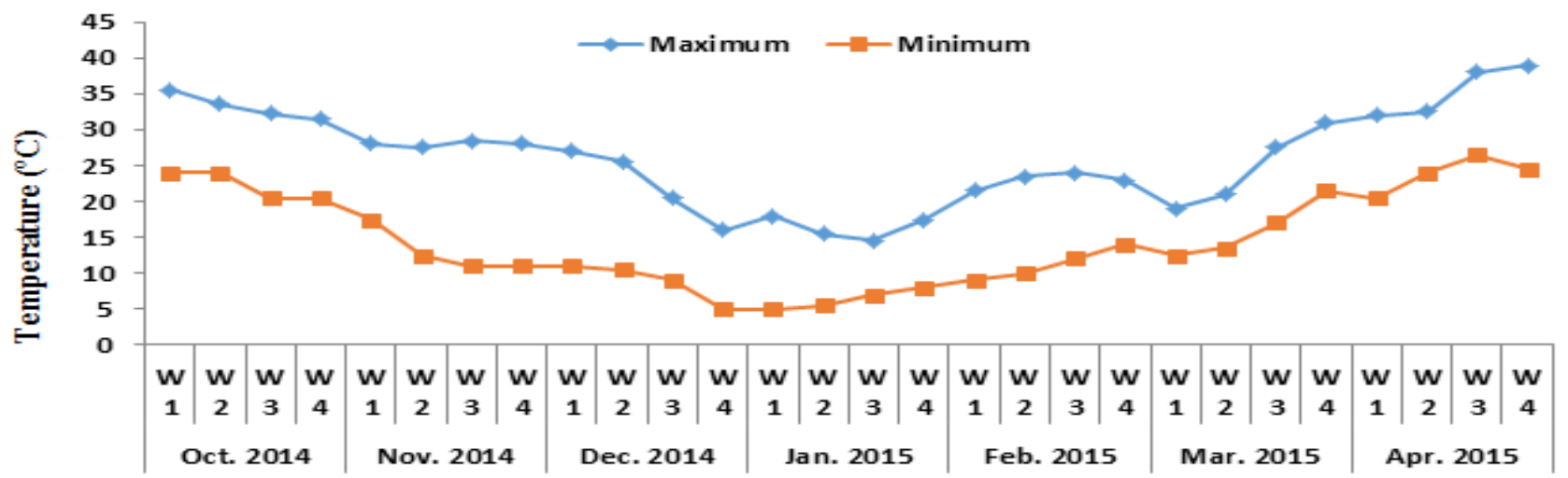

Figure 1: Maximum and minimum temperatures during crop season

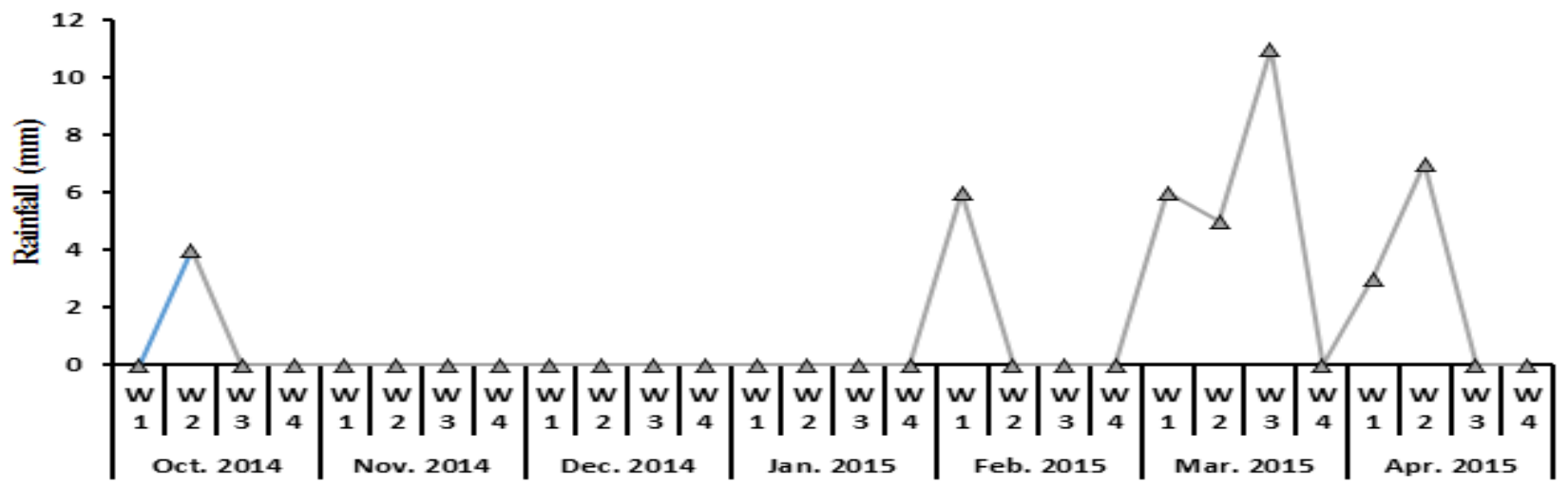

Figure 2: Rainfall distribution during crop season

Source: Cotton Research Institute, Regional Agricultural Research Institute Bahawalpur 
biofertilizer and P-enriched compost + biofertilizer. The experiments were conducted in Randomized Complete Block design with three replications. Recommended dose of $\mathrm{P}$ and $\mathrm{K} @ 60 \mathrm{~kg} \mathrm{ha}^{-1}$ while half of the recommended dose of nitrogen $\left(20 \mathrm{~kg} \mathrm{ha}^{-1}\right)$ was applied to each plot as basal dose and seeds of chickpea inoculated with multi-strain biofertilizer containing Mesorhizobium cicri, Pseudomonas sp. and Bacillus sp. were sown. Sowing was done by hand drill and row to row distance was maintained $30 \mathrm{~cm}$ while plant to plant distance $5-7 \mathrm{~cm}$. All the agronomic practices were carried out as and when required.

\section{Data recording and analysis}

Nodulation data were recorded at flowering by carefully uprooting the plants with enough surrounding soil keeping in view that minimal damage to roots occur. Five plants per experimental unit were uprooted along with rhizospheric soil, washed thoroughly under running water on a sieve of mesh size that don't allow nodules to pass through but the soil. Nodules were counted and fresh as well as oven dry weight was recorded. At harvesting, plant agronomic data were recorded and samples were collected for analyses. Dried ground plant material was digested according to the method of Wolf (1982) and N, P and K concentration was determined as described by Ryan et al. (2001).

Physiological parameters i.e. chlorophyll-a, and chlorophyll-b contents in leaves were recorded at physiological maturity by extracting leaf material (0.05 g) in $10 \mathrm{~mL}$ dimethylsulfoxide (Hiscox and Israelstam, 1979). The samples were heated at $65{ }^{\circ} \mathrm{C}$ for $4 \mathrm{~h}$ and then the absorbance of extract was recorded at 663 and $645 \mathrm{~nm}$ as described by Arnon (1949). Data were subjected to statistical analysis by using LSD technique at 5\% level of significance (Steel et al., 1997).

\section{Results}

Results showed that the application of biofertilizer and P-enriched compost improved the root growth and nodulation in chickpea grown under field conditions (Figure 3). The data regarding number of nodules plant ${ }^{-1}$ (Table 1) showed that the application of biofertilizer and $\mathrm{P}$ enriched compost individually and in combination showed significant increase in number of nodules in chickpea at all sites. With the application of biofertilizer maximum increase in in number of nodules plant ${ }^{-1}$ as compared to control was observed at site $16 \mathrm{BC}$ that was $126 \%$ higher than control. The combined application of P-enriched compost and biofertilizer resulted in maximum increase $(230 \%)$ in number of nodules as compared to un-inoculated control at the same site. There was a variation in the effectiveness of treatments at different sites.
The results showed that nodules fresh weight (Table 2) was significantly improved with the application of biofertilizer and P-enriched compost solely and in combination. When P-enriched compost was applied there was 2 fold increase in nodules fresh weight and with the application of biofertilizer 3 fold increase in nodules fresh weight was observed as compared to control at $15 \mathrm{BC}$. The combined application of P-enriched compost and biofertilizer resulted in maximum increase ( 5 fold) in nodules fresh weight at the same site and it was also significantly better than other treatments at all experimental sites with exception of $13 \mathrm{BC}$ where no significant difference in nodules fresh weight was observed among the combined or sole application of biofertilizer and P-enriched compost. As in case of nodules fresh weight nodules dry weight was also significantly improved with the application of biofertilizer and P-enriched compost solely and in combination (Table 3). Maximum increase was observed in case of combined application of $\mathrm{P}$-enriched compost and biofertilizer at $15 \mathrm{BC}$ that resulted up to 3 fold increase in nodules dry weight as compared to control.

The data regarding plant height (Table 4) revealed that the application of biofertilizer and P-enriched compost significantly improved the plant height of chickpea, grown at different locations. When P-enriched compost was applied individually, there was $11 \%$ increase in plant height in the experiment conducted at Baghdad. With the separate use of biofertilizer, plant height increased up to $16 \%$ at different locations. While the combined application of biofertilizer and P-enriched compost gave significantly better results and resulted in $22 \%$ increase in plant height at Baghdad. Significant increase in shoot dry weight with the application of P-enriched compost and biofertilizer has also been observed. Separate application of biofertilizer and Penriched compost significantly increased shoot dry weight in chickpea. The combined application of biofertilizer and P-enriched compost showed significantly higher increase in shoot dry weight as compared to other treatments where $74 \%$ increase in shoot dry weight was observed as compared to control at the experimental site 118 DB (Table $5)$.

The results (Table 6) showed that the use of biofertilizer and P-enriched compost separately as well as in combination caused a significant increase in number of pod plant $^{-1}$. The sole application of P-enriched compost and biofertilizer resulted in up to 27 and $44 \%$ increase in number of pods plant $^{-1}$, respectively. The combined application of biofertilizer and enriched compost resulted in significantly higher increase in number of pod plant ${ }^{-1}$ as compared to P-enriched compost and biofertilizer where $61 \%$ increase in number of pods plant $^{-1}$ as compared to control was observed at the experimental site Jageer bhati 
dari. The number of grains pod ${ }^{-1}$ also significantly improved with the application of biofertilizer and P-enriched compost, solely and in combination (Table 7). Maximum increase in number of grains pod $^{-1}$ was observed when biofertilizer was applied in combination with $\mathrm{P}$-enriched compost. However, no significant difference was observed between sole application of biofertilizer and in combination with P-enriched compost.

The data presented in Table 8 showed that of 1000 grain weight was significantly improved with the application of biofertilizer and P-enriched compost. When enriched compost and biofertilizer (Table 9). The separate application of biofertilizer and P-enriched compost increased the grain yield up to 32 and $10 \%$, respectively, while the combined application of biofertilizer and $\mathrm{P}$ enriched compost resulted in significantly higher increase in grain yield as compared to other treatments and the maximum increase was $51 \%$ as compared to control at the experimental site $15 \mathrm{BC}$.

The results regarding chlorophyll contents in leaves revealed that the use of biofertilizer and P-enriched compost resulted in significant increase in chlorophyll

Table 1: Effect of enriched compost and biofertilizer on number of nodules of chickpea

\begin{tabular}{|c|c|c|c|c|c|c|}
\hline \multirow{2}{*}{ Treatment } & \multicolumn{6}{|c|}{ No. of nodules $\left(\right.$ plant $\left.^{-1}\right)$} \\
\hline & $13 \mathrm{BC}$ & $15 \mathrm{BC}$ & $16 \mathrm{BC}$ & Baghdad & $118 \mathrm{DB}$ & Jageer bhati dari \\
\hline Control & $40 \mathrm{~d}$ & $27 \mathrm{c}$ & $23 \mathrm{~d}$ & $37 \mathrm{~d}$ & $38 \mathrm{~d}$ & $30 \mathrm{~d}$ \\
\hline Enriched compost (EC) & $52 \mathrm{c}$ & $26 \mathrm{c}$ & $38 \mathrm{c}$ & $51 \mathrm{c}$ & $49 \mathrm{c}$ & $39 \mathrm{c}$ \\
\hline Biofertilizer (B) & $62 \mathrm{~b}$ & $49 \mathrm{~b}$ & $52 \mathrm{~b}$ & $59 \mathrm{~b}$ & $61 \mathrm{~b}$ & $57 \mathrm{~b}$ \\
\hline $\mathrm{EC}+\mathrm{B}$ & $82 \mathrm{a}$ & $60 \mathrm{a}$ & $76 \mathrm{a}$ & $77 \mathrm{a}$ & $78 \mathrm{a}$ & $70 \mathrm{a}$ \\
\hline $\operatorname{LSD}(\mathrm{p} \leq 0.05)$ & 3.0518 & 3.7820 & 5.6115 & 3.5082 & 2.2828 & 4.8231 \\
\hline
\end{tabular}

Table 2: Effect of enriched compost and biofertilizer on nodules fresh weight of chickpea

\begin{tabular}{|c|c|c|c|c|c|c|}
\hline \multirow{2}{*}{ Treatment } & \multicolumn{6}{|c|}{ Nodules fresh weight $\left(\mathrm{g} \mathrm{plant}^{-1}\right)$} \\
\hline & $13 \mathrm{BC}$ & $15 \mathrm{BC}$ & $16 \mathrm{BC}$ & Baghdad & $118 \mathrm{DB}$ & Jageer bhati dari \\
\hline Control & $0.81 \mathrm{~b}$ & $0.38 \mathrm{~d}$ & $0.51 \mathrm{~d}$ & $0.75 \mathrm{~d}$ & $0.74 \mathrm{~d}$ & $0.67 \mathrm{~d}$ \\
\hline Enriched compost EC) & $1.59 \mathrm{a}$ & $1.17 \mathrm{c}$ & $0.70 \mathrm{c}$ & $0.94 \mathrm{c}$ & $0.96 \mathrm{c}$ & $1.01 \mathrm{c}$ \\
\hline Biofertilizer (B) & $1.31 \mathrm{ab}$ & $1.88 \mathrm{~b}$ & $1.79 \mathrm{~b}$ & $1.09 \mathrm{~b}$ & $1.09 \mathrm{~b}$ & $1.31 \mathrm{~b}$ \\
\hline $\mathrm{EC}+\mathrm{B}$ & $1.81 \mathrm{a}$ & $2.53 \mathrm{a}$ & $2.28 \mathrm{a}$ & $1.33 \mathrm{a}$ & $1.30 \mathrm{a}$ & $1.51 \mathrm{a}$ \\
\hline $\operatorname{LSD}(\mathrm{p} \leq 0.05)$ & 0.5423 & 0.1045 & 0.2001 & 0.0443 & 0.0622 & 0.0537 \\
\hline
\end{tabular}

Table 3: Effect of enriched compost and biofertilizer on nodules dry weight of chickpea

\begin{tabular}{|c|c|c|c|c|c|c|}
\hline \multirow{2}{*}{ Treatment } & \multicolumn{6}{|c|}{ Nodules dry weight $\left(\right.$ g plant $\left.^{-1}\right)$} \\
\hline & $13 \mathrm{BC}$ & $15 \mathrm{BC}$ & $16 \mathrm{BC}$ & Baghdad & $118 \mathrm{DB}$ & Jageer bhati dari \\
\hline Control & $0.13 \mathrm{~d}$ & $0.08 \mathrm{~d}$ & $0.11 \mathrm{~d}$ & $0.36 \mathrm{~d}$ & $0.13 \mathrm{~d}$ & $0.16 \mathrm{~d}$ \\
\hline Enriched compost (EC) & $0.19 \mathrm{c}$ & $0.11 \mathrm{c}$ & $0.21 \mathrm{c}$ & $0.41 \mathrm{c}$ & $0.15 \mathrm{c}$ & $0.21 \mathrm{c}$ \\
\hline Biofertilizer (B) & $0.24 \mathrm{~b}$ & $0.17 \mathrm{~b}$ & $0.26 \mathrm{~b}$ & $0.52 \mathrm{~b}$ & $0.22 \mathrm{~b}$ & $0.36 \mathrm{~b}$ \\
\hline $\mathrm{EC}+\mathrm{B}$ & $0.31 \mathrm{a}$ & $0.33 \mathrm{a}$ & $0.32 \mathrm{a}$ & $0.61 \mathrm{a}$ & $0.29 \mathrm{a}$ & $0.41 \mathrm{a}$ \\
\hline $\operatorname{LSD}(\mathrm{p} \leq 0.05)$ & 0.0204 & 0.0931 & 0.0279 & 0.0296 & 0.0734 & 0.0831 \\
\hline
\end{tabular}

Means sharing same letters are statistically show insignificant results at par at $5 \%$ level of probability $(n=3)$

P-enriched compost was applied, maximum increase was observed at 118 DB where $17 \%$ increase in 1000 grain weight as compared to control was observed and with the sole application of biofertilizer $33 \%$ increase in 1000 grain weight as compared to control was observed at the same experimental site. Moreover, the combined application of P-enriched compost and biofertilizer resulted in maximum increase (40\%) in 1000 grain weight as compared to control at $118 \mathrm{DB}$. The grain yield was also significantly improved with the application of $\mathrm{P}$ - contents in leaves of chickpea. The combined application of biofertilizer and P-enriched compost resulted in significantly higher increase in chlorophyll ' $a$ ' contents in leaves as compared to other treatments (Table 10) where the increase was up to $19 \%$. Data regarding chlorophyll-b contents in leaves (Table 11) showed that in most of trials, there was no significant difference in chlorophyll-b contents in leaves between combined application of biofertilizer with P-enriched compost and sole application of biofertilizer. 
Data (Table 12) showed that the sole application of $\mathrm{P}$ enriched compost and biofertilizer significantly enhanced nitrogen concentration of grains in chickpea. The combined application of biofertilizer and P-enriched compost resulted in maximum increase in nitrogen concentration in grains of chickpea. The phosphorus concentration in grains also significantly increased with the application of biofertilizer and P-enriched compost (Table 13). The combined use of P-enriched compost and biofertilizer was more effective than separate use and resulted in maximum increase in phosphorus concentration in grains of chickpea. The application of treatments increased potassium concentration in grains of chickpea but there was increase was not significant as compared to control (Table 14).
Rhizobia make symbiotic associations with legume plants and help plants to grow vigorously through atmospheric nitrogen fixation and several other mechanisms. The ACC deaminase containing rhizobacteria in combination with Rhizobia have been well documented to improve the efficiency of Rhizobial inoculation especially under stressful environments (Ahmad et al., 2012, 2013c) thus they can be excellent supplement to chemical fertilizers for improving crop productivity.

Chickpea is a hardy crop that can grow under limited water conditions and sandy soils thus has the potential to fit well in several cropping sequences such as with maize, fodders and millets (Verma et al., 2013). It is generally grown on marginal lands (sandy soils) under irrigation

Table 4: Effect of enriched compost and biofertilizer on plant height of chickpea

\begin{tabular}{lcccccc}
\hline \multirow{2}{*}{ Treatment } & \multicolumn{5}{c}{ Plant height (cm) } \\
\cline { 2 - 7 } & 13 BC & 15 BC & 16 BC & Baghdad & 118 DB & Jageer bhati dari \\
\hline Control & $37.47 \mathrm{c}$ & $41.66 \mathrm{c}$ & $46.21 \mathrm{c}$ & $38.98 \mathrm{c}$ & $47.00 \mathrm{~b}$ & $43.07 \mathrm{c}$ \\
Enriched compost (EC) & $41.25 \mathrm{~b}$ & $44.61 \mathrm{~b}$ & $48.96 \mathrm{~b}$ & $43.15 \mathrm{~b}$ & $51.00 \mathrm{a}$ & $46.48 \mathrm{~b}$ \\
Biofertilizer (B) & $44.63 \mathrm{a}$ & $47.80 \mathrm{a}$ & $53.81 \mathrm{a}$ & $44.55 \mathrm{~b}$ & $54.00 \mathrm{a}$ & $49.78 \mathrm{ab}$ \\
EC + B & $45.58 \mathrm{a}$ & $48.59 \mathrm{a}$ & $54.63 \mathrm{a}$ & $47.71 \mathrm{a}$ & $54.33 \mathrm{a}$ & $51.46 \mathrm{a}$ \\
\hline LSD (p $\leq 0.05)$ & 2.4158 & 1.9489 & 1.8949 & 1.7532 & 3.6476 & 3.3838 \\
\hline
\end{tabular}

Table 5: Effect of enriched compost and biofertilizer on shoot dry weight of chickpea

\begin{tabular}{|c|c|c|c|c|c|c|}
\hline \multirow{2}{*}{ Treatment } & \multicolumn{6}{|c|}{ Shoot dry weight (g plant $\left.{ }^{-1}\right)$} \\
\hline & $13 \mathrm{BC}$ & $15 \mathrm{BC}$ & $16 \mathrm{BC}$ & Baghdad & $118 \mathrm{DB}$ & Jageer bhati dari \\
\hline Control & $10.29 \mathrm{c}$ & $12.04 \mathrm{c}$ & $10.78 \mathrm{~d}$ & $15.36 \mathrm{c}$ & $6.39 \mathrm{~b}$ & $7.11 \mathrm{c}$ \\
\hline Enriched compost (EC) & $12.18 \mathrm{~b}$ & $13.89 \mathrm{bc}$ & $12.71 \mathrm{c}$ & $16.27 \mathrm{c}$ & $7.26 \mathrm{ab}$ & $9.04 \mathrm{~b}$ \\
\hline Biofertilizer $(\mathrm{B})$ & $15.29 \mathrm{a}$ & $15.17 \mathrm{~b}$ & $15.09 \mathrm{~b}$ & $17.87 \mathrm{~b}$ & $7.28 \mathrm{ab}$ & $9.78 \mathrm{~b}$ \\
\hline $\mathrm{EC}+\mathrm{B}$ & $15.36 \mathrm{a}$ & $17.70 \mathrm{a}$ & $16.54 \mathrm{a}$ & $19.43 \mathrm{a}$ & $11.10 \mathrm{a}$ & $11.10 \mathrm{a}$ \\
\hline $\operatorname{LSD}(\mathrm{p} \leq 0.05)$ & 1.7079 & 1.9631 & 1.1834 & 1.4724 & 1.0641 & 1.2259 \\
\hline
\end{tabular}

Table 6: Effect of enriched compost and biofertilizer on number of pods plant ${ }^{-1}$ in chickpea

\begin{tabular}{lcccccc}
\hline \multirow{2}{*}{ Treatment } & \multicolumn{6}{c}{ Number of pods plant $^{-1}$} \\
\cline { 2 - 7 } & 13 BC & 15 BC & 16 BC & Baghdad & 118 DB & Jageer bhati dari \\
\hline Control & $28.30 \mathrm{~d}$ & $30.74 \mathrm{~d}$ & $30.65 \mathrm{~d}$ & $29.63 \mathrm{~b}$ & $24.52 \mathrm{~d}$ & $25.52 \mathrm{c}$ \\
Enriched compost (EC) & $30.19 \mathrm{c}$ & $35.02 \mathrm{c}$ & $34.02 \mathrm{c}$ & $30.86 \mathrm{~b}$ & $31.22 \mathrm{c}$ & $32.06 \mathrm{~b}$ \\
Biofertilizer (B) & $36.04 \mathrm{~b}$ & $40.54 \mathrm{~b}$ & $37.92 \mathrm{~b}$ & $33.70 \mathrm{~b}$ & $35.49 \mathrm{~b}$ & $40.81 \mathrm{a}$ \\
EC + B & $38.17 \mathrm{a}$ & $47.25 \mathrm{a}$ & $40.37 \mathrm{a}$ & $37.84 \mathrm{a}$ & $38.15 \mathrm{a}$ & $41.02 \mathrm{a}$ \\
\hline LSD (p $\leq 0.05)$ & 1.1986 & 1.8372 & 1.7865 & 4.1106 & 1.9656 & 2.1224 \\
\hline
\end{tabular}

Means sharing same letters are statistically show insignificant results at par at $5 \%$ level of probability $(n=3)$

\section{Discussion}

The rhizosphere is the most active region of soil where diverse plant-soil microbe interactions take place. Endophytic and rhizospheric microbes have been reported to have beneficial effects on plant growth and productivity through a number of direct and indirect mechanisms (Nadeem et al. 2014). Among endophytic bacteria, conditions and in rainfed areas where water scarcity and increasingly variable and extreme weather conditions are the main problems. The ACC deaminase containing rhizobacterial based biofertilizers have been well documented to help crop plants to withstand extreme environmental conditions (Arshad et al., 2008; Ahmad et al., 2013b; Nadeem et al., 2014). The present study thus explores the effectiveness of multi-strain ACC deaminase 
containing biofertilizer to improve the productivity of chickpea under field conditions in Bahawalpur region where water availability is the major problem.
The results from our study showed that the inoculation with multi-strain biofertilizer containing novel strains of Mesorhizobium cicri, and ACC deaminase containing

Table 7: Effect of enriched compost and biofertilizer on number of grains pod $^{-1}$ in chickpea

\begin{tabular}{lcccccc}
\hline \multirow{2}{*}{ Treatment } & \multicolumn{6}{c}{ Number of grains pod $^{-1}$} \\
\cline { 2 - 7 } & $\mathbf{1 3 ~ B C}$ & $\mathbf{1 5} \mathbf{~ B C}$ & $\mathbf{1 6 ~ B C}$ & Baghdad $^{-118 ~ D B}$ & Jageer bhati dari $^{\text {Dagh }}$ \\
\hline Control & $1.31 \mathrm{c}$ & $1.32 \mathrm{c}$ & $1.25 \mathrm{c}$ & $1.16 \mathrm{c}$ & $1.09 \mathrm{c}$ & $1.29 \mathrm{~b}$ \\
Enriched compost (EC) & $1.36 \mathrm{~b}$ & $1.39 \mathrm{~b}$ & $1.31 \mathrm{~b}$ & $1.27 \mathrm{ab}$ & $1.22 \mathrm{~b}$ & $1.33 \mathrm{~b}$ \\
Biofertilizer (B) & $1.43 \mathrm{a}$ & $1.47 \mathrm{a}$ & $1.41 \mathrm{a}$ & $1.24 \mathrm{~b}$ & $1.28 \mathrm{a}$ & $1.40 \mathrm{a}$ \\
EC + B & $1.40 \mathrm{a}$ & $1.49 \mathrm{a}$ & $1.44 \mathrm{a}$ & $1.29 \mathrm{a}$ & $1.30 \mathrm{a}$ & $1.37 \mathrm{a}$ \\
\hline LSD $(\mathrm{p} \leq 0.05)$ & 0.0354 & 0.0593 & 0.0499 & 0.0435 & 0.0620 & 0.0421 \\
\hline
\end{tabular}

Table 8: Effect of enriched compost and biofertilizer on 1000 grain weight in chickpea

\begin{tabular}{lcccccc}
\hline \multirow{2}{*}{ Treatment } & \multicolumn{7}{c}{ 1000 grain weight $\mathbf{( g )}$} \\
\cline { 2 - 7 } & $\mathbf{1 3 ~ B C}$ & $\mathbf{1 5 ~ B C}$ & $\mathbf{1 6 ~ B C}$ & Baghdad & $\mathbf{1 1 8}$ DB & Jageer bhati dari \\
\hline Control & $199.00 \mathrm{c}$ & $259.33 \mathrm{~d}$ & $245.00 \mathrm{~d}$ & $274.67 \mathrm{~b}$ & $191.33 \mathrm{~d}$ & $202.00 \mathrm{~d}$ \\
Enriched compost (EC) & $205.33 \mathrm{~b}$ & $273.33 \mathrm{c}$ & $279.0 \mathrm{c}$ & $274.00 \mathrm{~b}$ & $224.67 \mathrm{c}$ & $225.00 \mathrm{c}$ \\
Biofertilizer (B) & $217.33 \mathrm{a}$ & $281.67 \mathrm{~b}$ & $301.67 \mathrm{~b}$ & $282.67 \mathrm{a}$ & $253.67 \mathrm{~b}$ & $244.67 \mathrm{~b}$ \\
EC + B & $220.67 \mathrm{a}$ & $294.00 \mathrm{a}$ & $339.67 \mathrm{a}$ & $288.67 \mathrm{a}$ & $267.00 \mathrm{a}$ & $255.33 \mathrm{a}$ \\
\hline LSD $(\mathrm{p} \leq 0.05)$ & 5.2120 & 6.5166 & 9.6220 & 7.5859 & 10.738 & 7.3332 \\
\hline
\end{tabular}

Table 9: Effect of enriched compost and biofertilizer on grain yield of chickpea

\begin{tabular}{lcccccc}
\hline \multirow{2}{*}{ Treatment } & \multicolumn{7}{c}{ Grain yield $\left(\mathbf{k g ~ a c r e}^{-1}\right)$} \\
\cline { 2 - 7 } & $\mathbf{1 3 ~ B C}$ & $\mathbf{1 5 ~ B C}$ & $\mathbf{1 6 ~ B C}$ & Baghdad & $\mathbf{1 1 8}$ DB & Jageer bhati dari \\
\hline Control & $648.33 \mathrm{~b}$ & $781.70 \mathrm{c}$ & $749.30 \mathrm{c}$ & $948.30 \mathrm{~b}$ & $848.30 \mathrm{~d}$ & $948.30 \mathrm{~b}$ \\
Enriched compost (EC) & $661.00 \mathrm{~b}$ & $861.00 \mathrm{bc}$ & $827.7 \mathrm{~b}$ & $967.70 \mathrm{~b}$ & $927.70 \mathrm{c}$ & $967.70 \mathrm{~b}$ \\
Biofertilizer (B) & $730.33 \mathrm{~b}$ & $1030.33 \mathrm{ab}$ & $897.0 \mathrm{~b}$ & $997.00 \mathrm{ab}$ & $997.00 \mathrm{~b}$ & $997.00 \mathrm{ab}$ \\
EC + B & $985.00 \mathrm{a}$ & $1180.30 \mathrm{a}$ & $1047.0 \mathrm{a}$ & $1087.34 \mathrm{a}$ & $1113.70 \mathrm{a}$ & $1072.31 \mathrm{a}$ \\
\hline LSD $(\mathrm{p} \leq 0.05)$ & 199.78 & 210.12 & 73.162 & 68.646 & 42.876 & 68.646 \\
\hline
\end{tabular}

Table 10: Effect of enriched compost and biofertilizer on chlorophyll-a contents in leaves of chickpea

\begin{tabular}{lcccccc}
\hline \multirow{2}{*}{ Treatment } & \multicolumn{5}{c}{ Chlorophyll-a contents $\left(\boldsymbol{\mu g} \mathbf{~ g}^{-\mathbf{1}}\right)$} \\
\cline { 2 - 7 } & $\mathbf{1 3 ~ B C}$ & $\mathbf{1 5 ~ B C}$ & $\mathbf{1 6 ~ B C}$ & Baghdad & $\mathbf{1 1 8 ~ D B}$ & Jageer bhati dari \\
\hline Control & $1.310 \mathrm{~b}$ & $1.330 \mathrm{~b}$ & $1.243 \mathrm{~b}$ & $1.306 \mathrm{c}$ & $1.130 \mathrm{c}$ & $1.223 \mathrm{~b}$ \\
Enriched compost (EC) & $1.343 \mathrm{~b}$ & $1.366 \mathrm{~b}$ & $1.306 \mathrm{ab}$ & $1.320 \mathrm{bc}$ & $1.253 \mathrm{~b}$ & $1.260 \mathrm{ab}$ \\
Biofertilizer (B) & $1.403 \mathrm{a}$ & $1.410 \mathrm{a}$ & $1.320 \mathrm{ab}$ & $1.343 \mathrm{~b}$ & $1.330 \mathrm{ab}$ & $1.306 \mathrm{ab}$ \\
EC + B & $1.406 \mathrm{a}$ & $1.420 \mathrm{a}$ & $1.383 \mathrm{a}$ & $1.390 \mathrm{a}$ & $1.353 \mathrm{a}$ & $1.360 \mathrm{a}$ \\
\hline LSD $(\mathrm{p} \leq 0.05)$ & 0.0390 & 0.0395 & 0.0847 & 0.0344 & 0.0881 & 0.1208 \\
\hline
\end{tabular}

Table 11: Effect of enriched compost and biofertilizer on chlorophyll-b contents in leaves of chickpea

\begin{tabular}{lcccccc}
\hline \multirow{2}{*}{ Treatment } & \multicolumn{5}{c}{ Chlorophyll-b contents $\left(\boldsymbol{\mu g} \mathbf{~ g}^{-\mathbf{1}}\right)$} \\
\cline { 2 - 7 } & $\mathbf{1 3 ~ B C}$ & $\mathbf{1 5 ~ B C}$ & $\mathbf{1 6 ~ B C}$ & Baghdad & $\mathbf{1 1 8} \mathbf{~ D B}$ & Jageer bhati dari \\
\hline Control & $0.530 \mathrm{c}$ & $0.646 \mathrm{~b}$ & $0.710 \mathrm{~b}$ & $0.676 \mathrm{c}$ & $0.560 \mathrm{a}$ & $0.506 \mathrm{~b}$ \\
Enriched compost (EC) & $0.546 \mathrm{bc}$ & $0.683 \mathrm{ab}$ & $0.750 \mathrm{a}$ & $0.696 \mathrm{bc}$ & $0.566 \mathrm{a}$ & $0.533 \mathrm{ab}$ \\
Biofertilizer (B) & $0.573 \mathrm{~b}$ & $0.720 \mathrm{a}$ & $0.770 \mathrm{a}$ & $0.713 \mathrm{~b}$ & $0.581 \mathrm{a}$ & $0.556 \mathrm{a}$ \\
EC + B & $0.610 \mathrm{a}$ & $0.720 \mathrm{a}$ & $0.776 \mathrm{a}$ & $0.753 \mathrm{a}$ & $0.610 \mathrm{a}$ & $0.570 \mathrm{a}$ \\
\hline LSD $(\mathrm{p} \leq 0.05)$ & 0.0303 & 0.0415 & 0.321 & 0.0245 & 0.1194 & 0.0372 \\
\hline
\end{tabular}

Means sharing same letters are statistically show insignificant results at par at $5 \%$ level of probability $(n=3)$ 
PGPR Pseudomonas sp. and Bacillus sp. significantly improved the nodulation in chickpea. Improvement in bioavailability of nutrients especially nitrogen is an important trait of Rhizobium based inoculants.

The improvement in nodulation in these studies might be due to more efficiency of inoculated Rhizobial strain that

Table 12: Effect of enriched compost and biofertilizer on nitrogen concentration in grains of chickpea

\begin{tabular}{lcccccc}
\hline \multirow{2}{*}{ Treatment } & \multicolumn{5}{c}{ Nitrogen concentration in grains (\%) } \\
\cline { 2 - 7 } & $\mathbf{1 3 ~ B C}$ & $\mathbf{1 5 ~ B C}$ & $\mathbf{1 6 ~ B C}$ & Baghdad & 118 DB & Jageer bhati dari \\
\hline Control & $1.38 \mathrm{c}$ & $1.60 \mathrm{c}$ & $1.61 \mathrm{c}$ & $1.41 \mathrm{~b}$ & $1.20 \mathrm{c}$ & $1.32 \mathrm{~b}$ \\
Enriched compost (EC) & $1.48 \mathrm{bc}$ & $1.60 \mathrm{c}$ & $1.84 \mathrm{~b}$ & $1.53 \mathrm{~b}$ & $1.32 \mathrm{~b}$ & $1.40 \mathrm{ab}$ \\
Biofertilizer (B) & $1.57 \mathrm{ab}$ & $1.85 \mathrm{~b}$ & $1.92 \mathrm{~b}$ & $1.79 \mathrm{a}$ & $1.42 \mathrm{~b}$ & $1.57 \mathrm{ab}$ \\
EC + B & $1.70 \mathrm{a}$ & $2.04 \mathrm{a}$ & $2.12 \mathrm{a}$ & $2.02 \mathrm{a}$ & $1.56 \mathrm{a}$ & $1.66 \mathrm{a}$ \\
\hline LSD $(\mathrm{p} \leq 0.05)$ & 0.1866 & 0.1005 & 0.1169 & 0.2336 & 0.1010 & 0.2641 \\
\hline
\end{tabular}

Table 13: Effect of enriched compost and biofertilizer on phosphorus concentration in grains of chickpea

\begin{tabular}{lcccccc}
\hline \multirow{2}{*}{ Treatment } & \multicolumn{5}{c}{ Phosphorus concentration in grains (\%) } \\
\cline { 2 - 7 } & 13 BC & 15 BC & 16 BC & Baghdad & 118 DB & Jageer bhati dari \\
\hline Control & $0.33 \mathrm{~d}$ & $0.35 \mathrm{c}$ & $0.29 \mathrm{c}$ & $0.36 \mathrm{c}$ & $0.33 \mathrm{c}$ & $0.44 \mathrm{a}$ \\
Enriched compost (EC) & $0.38 \mathrm{c}$ & $0.39 \mathrm{~b}$ & $0.31 \mathrm{~b}$ & $0.38 \mathrm{~b}$ & $0.43 \mathrm{a}$ & $0.47 \mathrm{a}$ \\
Biofertilizer (B) & $0.41 \mathrm{~b}$ & $0.38 \mathrm{~b}$ & $0.31 \mathrm{~b}$ & $0.39 \mathrm{~b}$ & $0.36 \mathrm{~b}$ & $0.45 \mathrm{a}$ \\
EC + B & $0.44 \mathrm{a}$ & $0.42 \mathrm{a}$ & $0.44 \mathrm{a}$ & $0.41 \mathrm{a}$ & $0.44 \mathrm{a}$ & $0.49 \mathrm{a}$ \\
\hline LSD $(\mathrm{p} \leq 0.05)$ & 0.0287 & 0.0301 & 0.0166 & 0.0122 & 0.0161 & 0.1932 \\
\hline
\end{tabular}

Table 14: Effect of enriched compost and biofertilizer on potassium concentration in grains of chickpea

\begin{tabular}{lcccccc}
\hline \multirow{2}{*}{ Treatment } & \multicolumn{5}{c}{ Potassium concentration in grains (\%) } \\
\cline { 2 - 7 } & $\mathbf{1 3 ~ B C}$ & $\mathbf{1 5 ~ B C}$ & $\mathbf{1 6 ~ B C}$ & Baghdad & 118 DB & Jageer bhati dari \\
\hline Control & $1.25 \mathrm{a}$ & $1.54 \mathrm{a}$ & $1.68 \mathrm{a}$ & $1.31 \mathrm{a}$ & $1.34 \mathrm{a}$ & $1.48 \mathrm{a}$ \\
Enriched compost (EC) & $1.26 \mathrm{a}$ & $1.56 \mathrm{a}$ & $1.70 \mathrm{a}$ & $1.40 \mathrm{ab}$ & $1.38 \mathrm{a}$ & $1.51 \mathrm{a}$ \\
Biofertilizer (B) & $1.29 \mathrm{a}$ & $1.57 \mathrm{a}$ & $1.69 \mathrm{a}$ & $1.35 \mathrm{~b}$ & $1.37 \mathrm{a}$ & $1.50 \mathrm{a}$ \\
EC + B & $1.30 \mathrm{a}$ & $1.63 \mathrm{a}$ & $1.73 \mathrm{a}$ & $1.60 \mathrm{~b}$ & $1.44 \mathrm{a}$ & $1.59 \mathrm{a}$ \\
\hline LSD (p $\leq 0.05)$ & 0.1190 & 0.1018 & 0.0696 & 0.2223 & 0.1443 & 0.1245 \\
\hline
\end{tabular}

Means sharing same letters are statistically show insignificant results at par at $5 \%$ level of probability $(n=3)$

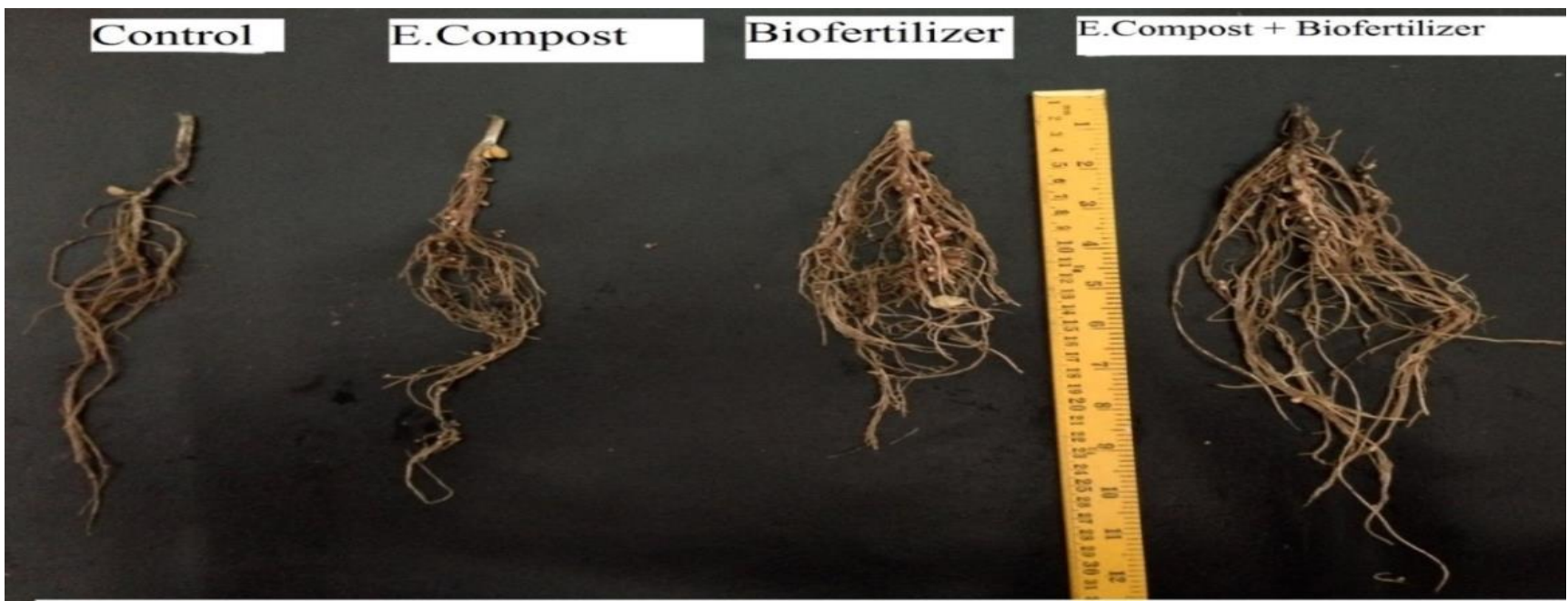

Figure 3: Effect of enriched compost and biofertilizer on nodulation in chickpea 
effectively colonized the plant roots under field conditions (Verma et al., 2012). It might also be due to the effectiveness of ACC deaminase containing rhizobacterial strains which increased root growth and proliferation under unfavorable conditions (Ahmad et al., 2011), increased surface area of roots, provided more infection sites for Rhizobial attachment to make nodules thus improving nodulation in chickpea. Similarly, Ahmad et al. (2013c) also reported the increased nodulation in mungbean due to combined use of Rhizobium and PGPR under salt-affected field conditions. Lowest nodulation in un-inoculated control elucidates decreased activity of native rhizobia but application of P-enriched compost and Rhizobium based multi-strain biofertilizer increased nodulation. It is advocated that the application of P-enriched compost resulted in increased Rhizobium bioactivity in rhizosphere and increased the root colonization of bacteria by improving physical properties of soil along with carbon and nutrient availability that promoted the nodulation (Zahran, 1999; Bashan et al., 2013).

In our study, the use of multi-strain biofertilizer and Penriched compost significantly increased yield attributes of chickpea. The findings are in line with the results from studies of Gharib et al. (2008) who reported that the use of biofertilizer and P-enriched compost enhanced crop yield significantly by improving the grain weight and number of grains. In case of combined application, in addition to the positive effects of P-enriched compost on soil physicochemical properties and crop growth, the bacterial strains present in the multi-strain biofertilizer enhanced the nitrogen and phosphorus availability, suppressed the possible negative effects of water shortage and improved root growth leading to improvement in yield and quality of chickpea. It has been well documented that promotion of root growth under stressed environment occurs due to decrease in ethylene levels by the ACC-deaminase activity of rhizobacterial strains (Shaharoona et al., 2006; Ahmad et al., 2012). Similarly, in previous study, it has been reported that PGPR inoculation increased the grain yield by suppressing the diseases (Vinale et al., 2008).

The combined application of multistrain biofertilizer and P-enriched compost can be more effective than separate use of biofertilizer. In these studies, the increase in growth and yield of chickpea could also be due to role of inoculated bacterial strains in nutrient acquisition by solubilization of phosphorus and other macro as well as micronutrients. Moreover, the bacterial strains might have effectively colonized the plant roots due to positive effect of P-enriched compost on soil properties which might have enhanced their efficiencies like $\mathrm{N}$ fixation, P-solubilization and effective pathogen suppression. Similarly, increasing nitrogen fixation due to phosphorus supplementation has been reported by Manjunath and
Bagyaraj, (1984). In another study, Rudresh et al. (2005) reported that nutrients availability plays an impartment role in increasing grains number per pod and grain weight under filed conditions.

This study demonstrated the effectiveness of multi-strain biofertilizer in combination with P-enriched compost for improving growth, yield and nutritional quality (N, P and $\mathrm{K}$ ) of chickpea under field conditions at different locations. The increase in grain quality could be attributed to the enhanced nutrient use efficiency in the presence of organic fertilizers and bio-inoculants. Studies have shown that the composted organic materials release nutrients slowly and may reduce the leaching losses, particularly of N (Muneshwar et al., 2001) and thus enhance nutrient use efficiency (Rudresh et al., 2005; Jutur and Reddy, 2007). This premise is further supported by the fact that total $\mathrm{N}$ and $\mathrm{P}$ uptakes in chickpea were significantly increased in response to combined application of biofertilizer and P-enriched compost. All these factors result in increased nutrient uptake leading to better quality of grains (Nevens and Reheul, 2003; Otieno et al., 2007). The increase in nutrient uptake may be due to increase in available $\mathrm{N}$ and $\mathrm{P}$ contents in the soil, and improved soil structure due to higher organic matter that increased nutrients availability and hence enhanced growth and quality of grains (Manna et al., 2001).

\section{Conclusion}

In the present study, the application of ACC deaminase containing multi-strain biofertilizer and P-enriched compost significantly enhanced the nodulation, growth, yield, grain quality and physiology of chickpea under field conditions at different locations in Bahawalpur. The integrated use of biofertilizer and P-enriched compost was effective at all experimental locations but their efficacy varied with locations / sites. It can be concluded that the use of multi-stain biofertilizer in combination with $\mathrm{P}$-enriched compost is significantly effective in improving the productivity and profitability of chickpea. So, the farmers should be recommended to adopt the ACC deaminase biofertilizer technology in combination with P-enriched compost for higher productivity of chickpea in the region.

\section{Acknowledgement}

The authors acknowledge the support provided by the research team during the execution of the project activities. We also acknowledge the facilities provided by the Islamia University of Bahawalpur, and University of Agriculture Faisalabad for project activities. Financial support was received from the research Competitive Grants Program, a joint initiative of the Planning Commission of Pakistan and the Pakistan Strategy Support Program, International Food Policy Research Institute (IFPRI), funded by USAID. 


\section{References}

Ahmad, M. Z.A. Zahir, S.M. Nadeem, F. Nazli, M. Jamil and M.U. Jamshaid. 2014. Physiological response of mung bean to Rhizobium and Pseudomonas based biofertilizers under salinity stress. Pakistan Journal of Agricultural Sciences 51(3): 1-8.

Ahmad, M., Z.A. Zahir, M. Khalid, F. Nazli and M. Arshad. 2013a. Efficacy of Rhizobium and Pseudomonas strains to improve physiology, ionic balance and quality of mung bean under salt-affected conditions on farmer's fields. Plant Physiology and Biochemistry 63: 170-176.

Ahmad, M., Z.A. Zahir, F. Nazli, F. Akram, M. Arshad and M. Khalid. 2013b. Effectiveness of halo-tolerant, auxin producing Pseudomonas and Rhizobium strains to improve osmotic stress tolerance in mung bean (Vigna radiata L.). Brazilian Journal of Microbiology 44(4):1341-1348.

Ahmad, M., Z.A. Zahir, S.M. Nadeem, F. Nazli, M. Jamil and M. Khalid. 2013c. Field evaluation of Rhizobium and Pseudomonas strains to improve growth, nodulation and yield of mung bean under salt-affected conditions. Soil and Environment 32(2): 158-166.

Ahmad, M., Z.A. Zahir, H.N. Asghar and M. Arshad. 2012. The combined application of rhizobial strains and plant growth promoting rhizobacteria improves growth and productivity of mung bean (Vigna radiata L.) under salt-stressed conditions. Annals of Microbiology 62: 1321-30.

Ahmad, M., Z.A. Zahir, H.N. Asghar and M. Asghar. 2011. Inducing salt tolerance in mung bean through coinoculation with Rhizobium and PGPR containing ACC-deaminase. Canadian Journal of Microbiology 57(7): 578-589.

Arnoldi, A., C. Zanoni, C. Lammi and G. Boschin. 2015. The role of grain legumes in the prevention of hypercholesterolemia and hypertension. Critical Review in Plant Sciences 34: 144-168.

Arnon, D.I. 1949. Copper enzymes in isolated chloroplasts, polyphenoxidase in Beta vulgaris. Plant Physiology 24: $1-15$.

Arshad, M., B. Shaharoona and T. Mahmood. 2008. Inoculation with Pseudomonas spp. containing ACCdeaminase partially eliminates the effects of drought stress on growth, yield, and ripening of pea (Pisum sativum L.). Pedosphere 18: 611-620.

Bashan, Y., A.A. Kamnev and L.E. de-Bashan. 2013. A proposal for isolating and testing phosphatesolubilizing bacteria that enhance plant growth. Biology and Fertility of Soils 49: 1-2.

Bent, E., S. Tuzun, C.P. Chanway and S. Enebak. 2001. Alterations in plant growth and in root hormone levels of lodge pole pines inoculated with rhizobacteria. Canadian Journal of Microbiology 47: 793-800.

Duc, G., H. Agrama, S. Bao, J. Berger, V. Bourion, A.M. De Ron, C.L.L. Gowda, A. Mikic, D. Millot, K.B. Singh, A. Tullu, A. Vandenberg, M.C. Vaz Patto, T.D. Warkentin and X. Zong. 2014. Breeding annual grain legumes for sustainable agriculture: new methods to approach complex traits and target new cultivar ideotypes. Critical Review in Plant Sciences 34: 381411.

FAO, 2015. FAOSTAT. Food and Agriculture Organization of the United Nations. http://faostat.fao.org/site/ 291/default.aspx.

Gharib, F.A., A. Lobna, Moussa and N.O. Massoud. 2008. Effect of compost and bio-fertilizers on growth, yield and essential oil of sweet marjoram (Majorana hortensis) plant. International Journal of Agriculture and Biology 10: 381-387.

Hiscox, J.D. and G.F. Israelstam. 1979. A method for the extraction of chlorophyll from leaf tissue without maceration. Canadian Journal of Botany 57: 13321334.

Hussain, M.B., A.A. Zahir, H.N. Asghar and M. Asgher. 2014. Can catalase and exopolysaccharides producing rhizobia ameliorate drought stress in wheat? International Journal of Agriculture and Biology 16(1): 3-13.

Jukanti, A.K., P.M. Gaur, C.L.L. Gowda and R.N. Chibbar, 2012. Nutritional quality and health benefits of chickpea (Cicer arietinum L.): a review. Brazilian Journal of Nutrition 108: 11-26.

Jutur, P.P. and A.R. Reddy. 2007. Isolation, purification and properties of new restriction endonucleases from Bacillus badius and Bacillus lentus. Microbiology Research 162: 378-383.

Manjunath, A., and D.J. Bagyaraj. 1984. Response of pigeon pea and cowpea to phosphorus and dual inoculation with vesicular arbuscular Mycorrhiza and Rhizobium. Tropical Agriculture 61: 48-52.

Manna, M.C., P.K. Ghosh, B.N. Ghosh and K.N. Singh. 2001. Comparative effectiveness of phosphate-enriched compost and single super- phosphate on yield, uptake of nutrients and soil quality under soybean-wheat rotation. Journal Agricultural Science 137: 45-54.

Muneshwar, S., V.P. Singh, K.S. Reddy and M. Singh. 2001. Effect of integrated use of fertilizer nitrogen and farmyard manure or green manure on transformation of $\mathrm{N}, \mathrm{K}$ and $\mathrm{S}$ and productivity of rice-wheat system on a vertisol. Journal of Indian Society of Soil Science 49: 430-435.

Nadeem, S.M., M. Ahmad, Z.A. Zahir, A. Javaid and M. Ashraf. 2014. The role of mycorrhizae and plant growth promoting rhizobacteria (PGPR) in improving 
crop productivity under stressful environments. Biotechnology Advances 32: 429-448.

Nevens, F. and D. Reheul. 2003. The application of vegetable, fruit and garden waste (VFG) compost in addition to cattle slurry in a silage maize monoculture: nitrogen availability and use. European Journal of Agronomy 19: 189-203.

Otieno, P.E., J.W. Muthomi, G.N. Cheminingwa and J.H. Nderitu. 2007. Effect of rhizobia inoculation, farmyard manure and nitrogen fertilizer on growth, nodulation and yield of selected food grain legumes. Proceedings of African Crop Science Conference 8:305-312.

Patten, C.L. and B.R. Glick. 2002. Role of Pseudomonas putida indole acetic acid in development of the host plant root system. Applied and Environmental Microbiology 68: 3795-3801.

Rubiales, D. and A. Mikic. 2015. Introduction: legumes in sustainable agriculture. Critical Review in Plant Sciences 34: 2-3.

Rudresh, D.L., M.K. Shivaprakash and R.D. Prasad. 2005. Effect of combined application of rhizobium, phosphate solubilizing bacterium and Trichoderma spp. on growth, nutrient uptake and yield of chickpea (Cicer aritenium L.). Applied Soil Ecology 28: 139146.

Ryan, J., G. Estefan and A. Rashid. 2001. Soil and Plant Analysis Laboratory Manual, 2nd Ed. International Center for Agriculture in Dry Areas (ICARDA), Syria.

Selvakumar, G., S. Reetha and P. Thamizhiniyan. 2012. Response of biofertilizers on growth, yield attributes and associated protein profiling changes of black gram (Vigna mungo L. Hepper). World Applied Science Journal 16: 1368-1374.

Shaharoona, B., M. Arshad and Z.A. Zahir. 2006. Effect of plant growth promoting rhizobacteria containing ACC-deaminase on maize (Zea mays L.) growth under axenic conditions and on nodulation in mung bean (Vigna radiata L.). Letters in Applied Microbiology 42(2): 155-159.

Singh, R.K. and D. Mukherjee. 2009. Influence of biofertilizers, fertility levels and weed management practices on chickpea (Cicer arietinum L.) under late sown condition. Annals of Agricultural Research 30: 116-120.

Steel, R.G.D., J.H. Torrie and D.A. Dickey. 1997. Principles and Procedures of Statistics: A Biometrical Approach. $3^{\text {rd }}$ Ed. WCB/McGraw-Hill, Boston, Mass., USA.

Verma, J.P. J. Yadav, K.N. Tiwari and A. Kumar. 2013. Effect of indigenous Mesorhizobium spp. and plant growth promoting rhizobacteria on yields and nutrient uptake of chickpea (Cicer arietinum L.) under sustainable agriculture. Ecological Engineering 51: 282-286.

Verma, J.P., J. Yadav and K.N. Tiwari. 2012. Enhancement of nodulation and yield of chickpea by co-inoculation of indigenous Mesorhizobium spp. and plant growthpromoting rhizobacteria in eastern Uttar Pradesh. Communications in Soil Science and Plant Analysis 43: 605-621.

Vinale, F., K. Sivasithamparam, E.L. Ghisalberti, S.L. Woo and M. Lorito. 2008. Trichoderma-plant-pathogen interactions. Soil Biology and Biochemistry 40: 1-10.

Wolf, B. 1982. The comprehensive system of leaf analysis and its use for diagnosing crop nutrient status. Communications in Soil Science and Plant Analysis 13: 1035-1059.

Zahran, H.H. 1999. Rhizobium-legume symbiosis and nitrogen fixation under severe conditions and in an arid climate. Microbiology and Molecular Biology Reviews 63: 968-989. 